\title{
Ancient DNA from the extinct South American giant glyptodont Doedicurus sp. (Xenarthra: Glyptodontidae) reveals that glyptodonts evolved from Eocene armadillos
}

\author{
KIEREN J. MITCHELL,$*$ AGUSTIN SCANFERLA, $\uparrow$ ESTEBAN SOIBELZON, + RICARDO BONINI, $\$$ \\ JAVIER OCHOA $\S$ and ALAN COOPER* \\ *Australian Centre for Ancient DNA, School of Biological Sciences, University of Adelaide, Adelaide, SA 5005, Australia, \\ †CONICET-Instituto de Bio y Geociencias del NOA (IBIGEO), 9 de Julio No 14 (A4405BBB), Rosario de Lerma, Salta, \\ Argentina, $\$$ Division Paleontologia de Vertebrados, Facultad de Ciencias Naturales y Museo (UNLP), CONICET, Museo de La \\ Plata, Paseo del Bosque, La Plata, Buenos Aires 1900, Argentina, §Museo Arqueológico e Histórico Regional 'Florentino \\ Ameghino', Int De Buono y San Pedro, Río Tercero, Córdoba X5850, Argentina
}

\begin{abstract}
Glyptodonts were giant (some of them up to $\sim 2400 \mathrm{~kg}$ ), heavily armoured relatives of living armadillos, which became extinct during the Late Pleistocene/early Holocene alongside much of the South American megafauna. Although glyptodonts were an important component of Cenozoic South American faunas, their early evolution and phylogenetic affinities within the order Cingulata (armoured New World placental mammals) remain controversial. In this study, we used hybridization enrichment and high-throughput sequencing to obtain a partial mitochondrial genome from Doedicurus sp., the largest (1.5 m tall, and $4 \mathrm{~m}$ long) and one of the last surviving glyptodonts. Our molecular phylogenetic analyses revealed that glyptodonts fall within the diversity of living armadillos. Reanalysis of morphological data using a molecular 'backbone constraint' revealed several morphological characters that supported a close relationship between glyptodonts and the tiny extant fairy armadillos (Chlamyphorinae). This is surprising as these taxa are among the most derived cingulates: glyptodonts were generally large-bodied and heavily armoured, while the fairy armadillos are tiny $(-9-17 \mathrm{~cm})$ and adapted for burrowing. Calibration of our phylogeny with the first appearance of glyptodonts in the Eocene resulted in a more precise timeline for xenarthran evolution. The osteological novelties of glyptodonts and their specialization for grazing appear to have evolved rapidly during the Late Eocene to Early Miocene, coincident with global temperature decreases and a shift from wet closed forest towards drier open woodland and grassland across much of South America. This environmental change may have driven the evolution of glyptodonts, culminating in the bizarre giant forms of the Pleistocene.
\end{abstract}

Keywords: macroevolution, mammals, systematics

Received 27 January 2016; revision received 6 April 2016; accepted 17 April 2016

\section{Introduction}

Glyptodonts were perhaps one of the most bizarre mammal groups ever to have evolved, with short deep skulls, fused vertebral columns, immobile carapaces

Correspondence: Kieren J. Mitchell, Fax: +61 88313 4364;

E-mail: kieren.mitchell@adelaide.edu.au made from hundreds of tessellated bone scutes (osteoderms) and bony tails that-in many species-ended with formidable clubs (Gillette \& Ray 1981; Soibelzon et al. 2006; Zurita et al. 2010). They were one of the most abundant, diverse and conspicuous elements of the isolated South American mammal fauna throughout much of the late Cenozoic (Rose 2006; Soibelzon et al. 2006; Zurita et al. 2009a,b, 2013). Glyptodonts were found in 
environments ranging from diverse forest types to coldopen grasslands and while predominantly South American, moved north into Central America and the southern United States (from Arizona to Florida and South Carolina) during the Great American Biotic Interchange (GABI; Cione et al. 2015) along with armadillos and another close relative, the pampatheres (Pampatheriidae). The latter were intermediate in size (up to $200 \mathrm{~kg}$ ) and carapace flexibility between armadillos and glyptodonts (see Góis et al. 2015) and appear to have had a separate evolutionary history since at least the Miocene (Gaudin \& Croft 2015). Unlike the armadillos, glyptodonts and pampatheres both became extinct at the end of the Pleistocene-early Holocene along with a large proportion of the world's megafauna (Barnosky et al. 2004; Prescott et al. 2012; Stegner \& Holmes 2013; Cione et al. 2015).

The name 'glyptodont' refers to their deeply carved or grooved teeth. These teeth grew continuously throughout an individual's life and, along with their peculiarly proportioned deep and massive jaws, suggest that glyptodonts were grazers feeding exclusively on fibrous plant matter (Farina \& Vizcaíno 2001; Vizcaíno et al. 2004). Each species had a rigid dorsal carapace and disarticulated ventral armour made up of fused osteoderms (up to $2.5 \mathrm{~cm}$ thick). They also had a cephalic shield, essentially a massive cap that protected the individual's head (Zurita et al. 2010). The weight of this armour was supported by a broad pectoral girdle, short massive limbs, and fused vertebrae. The body mass of some glyptodonts (up to $\sim 2400 \mathrm{~kg}$ ) was further counterbalanced by long muscular tails ringed by yet more osteoderms. In many species, these tails also ended with a formidable club, which, based on the distribution of carapace thickness and impact marks, may have been used in within-species competition, as well as for defence (Alexander et al. 1999; Blanco et al. 2009).

It is well accepted that glyptodonts (Glyptodontidae sensu McKenna \& Bell 1997) are members of the monophyletic group Xenarthra (e.g. Gillette \& Ray 1981; Rose 2006), one of the three major placental mammal lineages, which comprises the predominantly South American anteaters (Vermilingua), sloths (Folivora) and armadillos (Cingulata). However, while glyptodonts appear to be more closely related to armadillos than to the clade comprising anteaters and sloths (Pilosa), their precise phylogenetic affinities remain uncertain (Fernicola 2008; Porpino et al. 2010; Zurita et al. 2013).

Armadillos are the only remaining extant members of Cingulata and comprise approximately 20 species traditionally included in the family Dasypodidae (Nowack 1999; Gardner 2005). Recently, Gibb et al. (2015) divided Dasypodidae into two families, Dasypodidae and Chlamyphoridae, the former containing only a single extant subfamily (Dasypodinae-long-nosed, nine- and seven-banded armadillos) and the latter comprising three subfamilies (Chlamyphorinae-fairy armadillos; Euphractinae-hairy, dwarf and six-banded armadillos; and Tolypeutinae-naked-tailed, giant and threebanded armadillos). Past palaeontological studies have suggested that glyptodonts (along with pampatheriids) form a clade (Glyptodontoidea sensu McKenna \& Bell 1997) that is reciprocally monophyletic with respect to the extant armadillos (Patterson \& Pascual 1968, 1972; Engelmann 1985). However, more recent studies involving phylogenetic analyses of morphological characters have tentatively suggested a close relationship between glyptodonts and the armadillo subfamily Euphractinae - the six-banded armadillo, dwarf and hairy armadillos - to the exclusion of the remaining extant armadillos (Gaudin \& Wible 2006; Billet et al. 2011). The phylogenetic position of Glyptodontidae relative to extant armadillos is important for calibrating the evolutionary timescale of Cingulata, given the unequivocal, but incomplete glyptodont remains known from the Late Eocene (Simpson 1948). Such a record is necessary to understand the morphological evolution of the evolutionary adaptations in this unique group of mammals.

The relatively recent extinction of glyptodonts suggests that it should be possible to isolate ancient DNA (aDNA) from their subfossil remains, as has been possible for other South American megafauna (e.g. Hoss et al. 1996; Greenwood et al. 2001; Orlando et al. 2008, 2009; Clack et al. 2012). Further, the recent advent of highthroughput sequencing and hybridization enrichment has dramatically improved our ability to retrieve aDNA sequences from especially degraded specimens (e.g. Llamas et al. 2014; Mitchell et al. 2014). However, no aDNA has thus far been sequenced for any representative of Glyptodontidae. To resolve the phylogenetic position of glyptodonts, we analysed a carapace fragment (scute) from Doedicurus sp., the largest known glyptodonts (at around $1900-2400 \mathrm{~kg}, 1.5 \mathrm{~m}$ height and $4 \mathrm{~m}$ length) from which we sequenced a partial mitochondrial genome (mitogenome). We analysed these new genetic data in conjunction with a previously published data set of xenarthran mitogenomes (Gibb et al. 2015) and a matrix of 125 cranial morphological characters (Billet et al. 2011).

\section{Methods}

\section{Sampling details}

Specimens for aDNA analysis were obtained from remains found during a paleontological rescue operation of a rich locality located along the Salado River, Buenos Aires Province, Argentina (Scanferla et al. 2013). 
The fossil-bearing level consists of sandy-clayed sediments with abundant organic matter, gypsum and carbonate concretions that were deposited in a small pond environment, partially filled by aeolian sediments. This fossil-bearing level is attributable to the Luján Formation (Scanferla et al. 2013; Fucks et al. 2015). We recovered carcasses and disarticulated skeletal remains belonging to four extinct mammal species, including several carapace fragments and long bones of Doedicurus sp., along with plant macrofossils, herbivore dung, freshwater molluscs and insects. The high collagen yield of recovered bones ( $20 \mathrm{wt} \%$ ) suggested that specimens from this site had not undergone significant diagenetic alteration. According to ${ }^{14} \mathrm{C}$ dating of bone collagen, this level can be approximately constrained to between 13500 and $12000{ }^{14} \mathrm{C}$ years BP (Supporting information), corresponding with the end of the Lujanian Age (Cione et al. 2015). We sampled one Doedicurus sp. carapace fragment by drilling several holes into it at low speed $(\sim 1000 \mathrm{rpm})$, which allowed several small pieces of bone to be isolated (ACAD15262) and subsequently transported to the Australian Centre for Ancient DNA for further processing and analysis.

\section{DNA extraction and sequencing}

All aDNA extraction and library preparation steps were performed in a purpose-built, physically isolated, ancient DNA laboratory at the Australian Centre for Ancient DNA, University of Adelaide. We reduced potential surface contamination of the Doedicurus sp. bone pieces by removing surfaces $(\sim 1 \mathrm{~mm})$ using a DREMEL tool, followed by UV irradiation for $15 \mathrm{~min}$. The bone was then powdered using a mikrodismembrator (Sartorius), and $0.2 \mathrm{~g}$ was lysed by rotational incubation at $37{ }^{\circ} \mathrm{C}$ overnight in $4 \mathrm{~mL}$ of $0.5 \mathrm{~m}$ EDTA pH 8.0, followed by a further incubation at $55{ }^{\circ} \mathrm{C}$ for $2 \mathrm{~h}$ with the addition of $60 \mu \mathrm{L}$ of proteinase-K. The released DNA was bounded, washed and eluted using a silica-based method (Brotherton et al. 2013).

We also acquired liver samples of dwarf armadillo and big hairy armadillo (Zaedyus pichiy and Chaetophractus villosus, respectively; La Pampa Province, Argentina, September 2012), and skin and osteoderms from the southern three-banded armadillo (Tolypeutes matacus; Formosa Province, Argentina, December 2012), which were collected as part of ongoing projects by the Agencia Nacional de Promoción Científica y Tecnológica (ANPCyT) and Consejo Nacional de Investigaciones Científicas y Técnicas (CONICET) of Argentina. These samples were imported into Australia under permit number IP13011958, held by Dr Jeremy Austin at the University of Adelaide. Extraction and library preparation for these modern specimens was performed in a clean laboratory at the University of Adelaide. To extract DNA from these specimens, we used a DNeasy Blood \& Tissue Kit (Qiagen) according to the manufacturer's protocol and eluted in $200 \mu \mathrm{L}$ of AE buffer. We fragmented the extracted DNA to approximately $200 \mathrm{bp}$ using a Covaris Focused-ultrasonicator.

From our extracted DNA, we created Illumina sequencing libraries with uniquely barcoded adapters, which we then enriched for mammal mitochondrial DNA using a commercially synthesized (MYcroarray, MI, USA) set of biotinylated RNA probes (Supporting information). The enriched libraries were diluted to $2 \mathrm{~nm}$ and run on an Illumina MiSeq using $2 \times 150 \mathrm{bp}$ (paired-end) sequencing chemistry. We used a custom pipeline to perform read demulitplexing, quality control, and adapter removal on the raw sequencing data, and assembled mitogenomes for our target taxa by mapping iteratively to previously published reference sequences (Supporting information). We obtained a final consensus sequence (GenBank Accession KX098449) comprising 8788 bp, which spanned 52.3\% of the reference length at a read depth of two or more.

\section{Phylogenetic analysis}

We aligned our new sequences with previously published xenarthran mitogenomes (Table S1, Supporting information) using the MUSCLE algorithm as implemented in GENEIOUS v8.1.6. We then used PARTITIONFINDER v1.1.1 (Lanfear et al. 2012) to determine the optimal partitioning scheme and substitution models for downstream analysis (Supporting information).

Using RAXML v8.2.0 (Stamatakis 2014), we performed a maximum-likelihood search for the best-scoring tree from 1000 bootstrap replicates (-f a -m MULTIGAMMA \# 1000) based on our partitioned data set.

Our partitioned MRBAYES v3.2.6 (Ronquist et al. 2012) analysis employed four separate runs of four Markov chains each (one cold and three incrementally heated) using default priors. Each chain ran for $10^{7}$ generations, sampling every 1000. Convergence in topology was assessed using the average standard deviation of clade (split) frequencies $(<0.02)$, while convergence in individual parameter values was assessed through broadly overlapping distributions and effective sample sizes $>200$ in TRACER v1.6 (http://tree.bio.ed.ac.uk/soft ware/tracer/). Sampled trees were summarized as a majority-rule consensus tree after discarding the first $10 \%$ of trees as burnin.

We also reanalysed a previously reported morphological matrix Billet et al. (2011) using PAUP* (Swofford 2002) and performed a heuristic search involving 1000 random addition replicates followed by 200 bootstrap replicates, with all morphological characters treated as 
unordered. We enforced a backbone constraint such that the relationships among all extant taxa sampled were consistent with our molecular results. Further, we enforced the monophyly of a clade comprising glyptodonts (represented by the Miocene Propalaehoplophorus), Chlamyphorinae and Tolypeutinae (as in Fig. 1), but allowed the relationships between these three lineages to be determined by morphological signal, as the molecular data were largely equivocal about this arrangement. The position of fossil taxa included in Billet et al. (2011)'s matrix (for which DNA data are unavailable) remained unconstrained and was determined solely by morphological signal. These fossil taxa include several extinct 'eutatine' armadillos (Eutatus, Proeutatus and Doellotatus), putative early euphractines (Proeuphractus, Macroeuphractus and Paleuphractus) and tolypeutines (Kuntinaru) and several other unusual 'basal' armadillos (Peltephilus, Stegotherium, Prozaedyus), along with the pampathere Vassalia.

\section{Molecular dating}

We used BEAST v1.8.2 (Drummond \& Rambaut 2007) to simultaneously infer the phylogeny and estimate the timeline for xenarthran evolution. We implemented a birth-death tree prior, a single lognormal relaxed clock model (with a rate multiplier parameter for each data partition), and constrained the age of three key nodes in accordance with the fossil record. To aid in convergence, we enforced the reciprocal monophyly of Cingulata and Pilosa (anteaters and sloths, the out-group).

We calibrated the root of the tree (the divergence between Cingulata and Pilosa) using a uniform distribution with a hard minimum at $47.6 \mathrm{Ma}$ and a hard maximum at $83.5 \mathrm{Ma}$. This minimum bound is based on the oldest known cingulate-Riostegotherium (Oliveira \& Bergqvist 1998; Bergvist et al. 2004) —from the Early Eocene of Brazil (Woodburne et al. 2014), while the maximum bound is based on the absence of recognizable xenarthrans from the diverse and welldocumented mammalian fauna of the CampanianMaastrichtian age Los Alamitos Formation in northern Patagonia (e.g. Chornogubsky 2011). In addition, we constrained the minimum age of the Doedicurus lineage to $33.9 \mathrm{Ma}$ based on the earliest known glyptodonts (Simpson 1948) from the Mustersan South American Land Mammal Age (SALMA), which corresponds to the Late Eocene (Kay et al. 1999). We also constrained the origin of the branch leading to extant Tolypeutinae with a minimum age of $26.0 \mathrm{Ma}$ based on the earliest known tolypeutine (Kuntinaru) from the Deseadan SALMA (Billet et al. 2011), which corresponds to the Late Oligocene (Kay et al. 1998). We implemented these latter two calibrations as lognormal distributions (standard deviation $=0.7$ ), as the fossils they are based on can reasonably be expected to substantially postdate the node being constrained. We set the prior mean for both distributions such that $97.5 \%$ of the prior postdated $65.5 \mathrm{Ma}$. This soft maximum bound reflects the absence of xenarthrans from the Tiupampan (Early Palaeocene) and Peligran (middle Palaeocene) faunas (Gelfo et al. 2009), but also the possibility that these regions may have been environmentally unsuitable for early xenarthrans (see Gaudin \& Croft 2015).

Our BEAST analysis was run three times using different starting trees to ensure convergence on the global optimum. Each analysis was run for $10^{8}$ generations sampling every $10^{5}$ with the first $10 \%$ of samples discarded as burnin. Parameter values were monitored in TRACER v1.6 (http://tree.bio.ed.ac.uk/software/tracer/) to ensure stationarity and ESSs $>200$. Sampled trees and parameter values from each run were combined before summarizing the results.

\section{Results and discussion}

Our Bayesian and maximum-likelihood analyses yielded identical tree topologies, and the relationships among living taxa (Fig. 1) were concordant with the results of previous molecular phylogenetic analyses (e.g. Delsuc et al. 2012; Gibb et al. 2015). However, in addition our analyses unequivocally demonstrated that the extinct glyptodonts fall within the diversity of living armadillos, forming a monophyletic clade with Chlamyphoridae (Chlamyphorinae, Tolypeutinae and Euphractinae) to the exclusion of Dasypodidae (Bayesian posterior probability [MRBAYES/BEAST], BPP $=1.0$ / 1.0, maximum-likelihood bootstrap, MLB $=100 \%$ ). Previous morphological analyses that included fossil taxa have also suggested that glyptodonts were potentially nested within Cingulata (Engelmann 1985; Gaudin \& Wible 2006; Gaudin \& McDonald 2008; Billet et al. 2011), although generally with weak support due to the low number of informative morphological characters available. Our molecular results suggest that substantial and comprehensive revision of cingulate taxonomy is necessary, with a possible outcome being that glyptodonts are assigned subfamily status within Chlamyphoridae.

The phylogenetically nested position of glyptodonts within extant armadillos means that unique glyptodont skeletal features such as the complex dermal armour, extensive fusion of vertebrae and pelvic girdle to the carapace, carved teeth, migration of the masticatory apparatus and telescoping process of the skull (Farina \& Vizcaíno 2001; Vizcaíno et al. 2004) evolved from an armadillo-like ancestor. This implies that the completely fused carapace of glyptodonts evolved from the flexible 


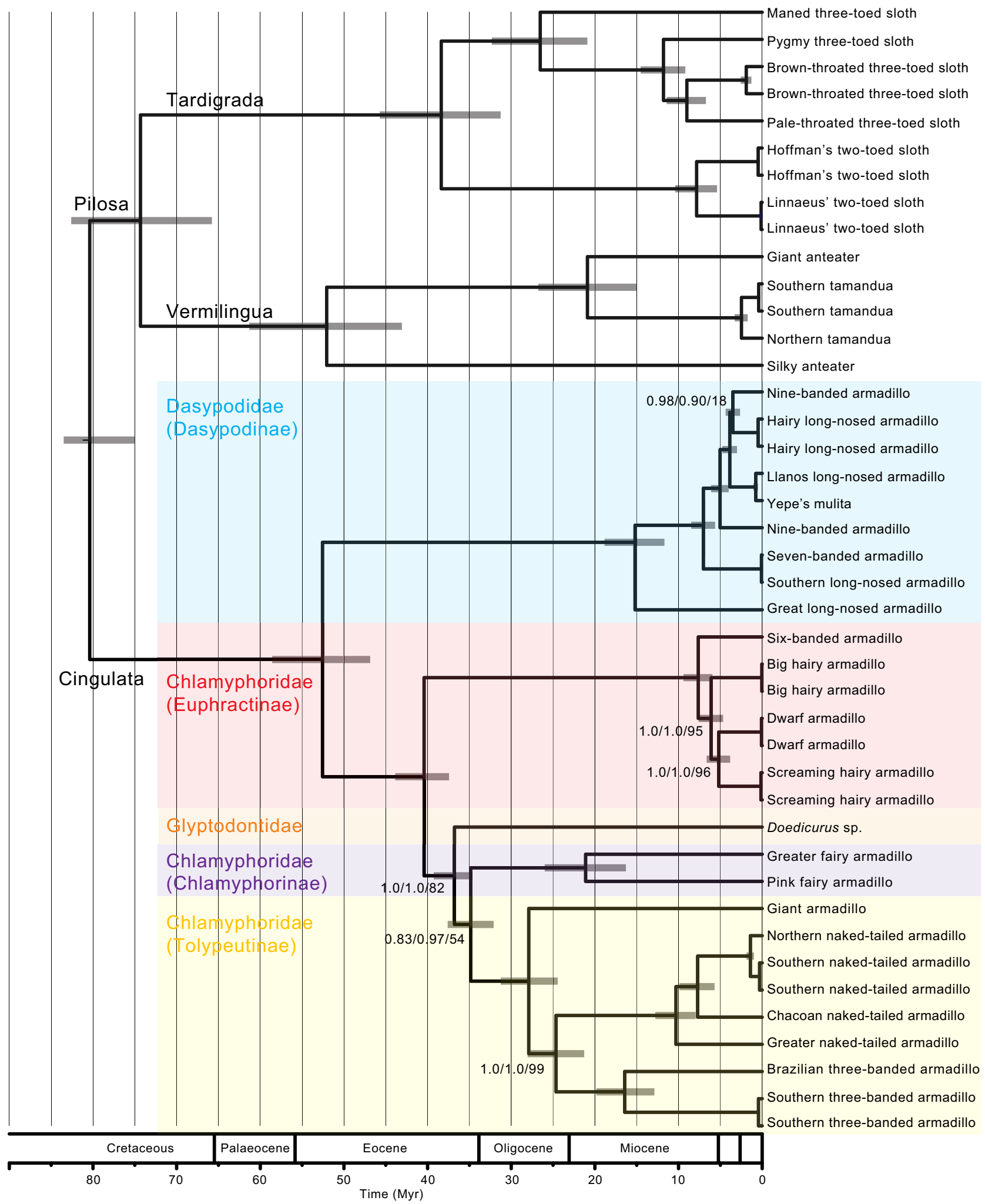

Fig. 1 Maximum clade credibility tree resulting from our time-calibrated BEAST analyses. Scale is in millions of years before the present. Node ages represent mean age estimates, while node bars represent 95\% highest posterior densities (HPDs). Branch support values (MrBayes posterior probability/BEAST posterior probability/maximum-likelihood bootstrap \%) are given for clades that received less than the maximum possible support (i.e. 1.0/1.0/100). 
banded armour of armadillos and that the strange 'lobate' dentition of glyptodonts is derived from relatively simple 'peg-like' teeth like those of living armadillos. These adaptations are potentially related to the shift from the standard armadillo insectivore niche to a grazing specialist and indicate the degree of plasticity and adaptive potential within early cingulates.

Within Chlamyphoridae, our results strongly support a clade comprising Doedicurus, Chlamyphorinae and Tolypeutinae $(\mathrm{BPP}=1.0 / 1.0, \mathrm{MLB}=82 \%)$, although the basal position of Doedicurus within this group is relatively weakly supported $(\mathrm{BPP}=0.83 / 0.97, \mathrm{MLB}=54 \%$ ). In this regard, our results conflict with the findings of Billet et al. (2011), who suggested that glyptodonts were more closely related to euphractine armadillos (hairy, dwarf and six-banded) than to the other living chlamyphorids (i.e. fairy, naked-tailed, giant and three-banded armadillos) based on their analysis of 125 cranial morphological characters. To further explore this conflict, we reanalysed Billet et al. (2011)'s morphological character matrix while constraining the topology to conform to our molecular results.

The single best-scoring tree recovered by our topologically constrained maximum parsimony analysis of Billet et al. (2011)'s data (Fig. 2) using PAUP* was 26 state changes longer than our best-scoring unconstrained tree (538 changes vs. 512 changes), suggesting that cingulate morphological evolution is much more complex than

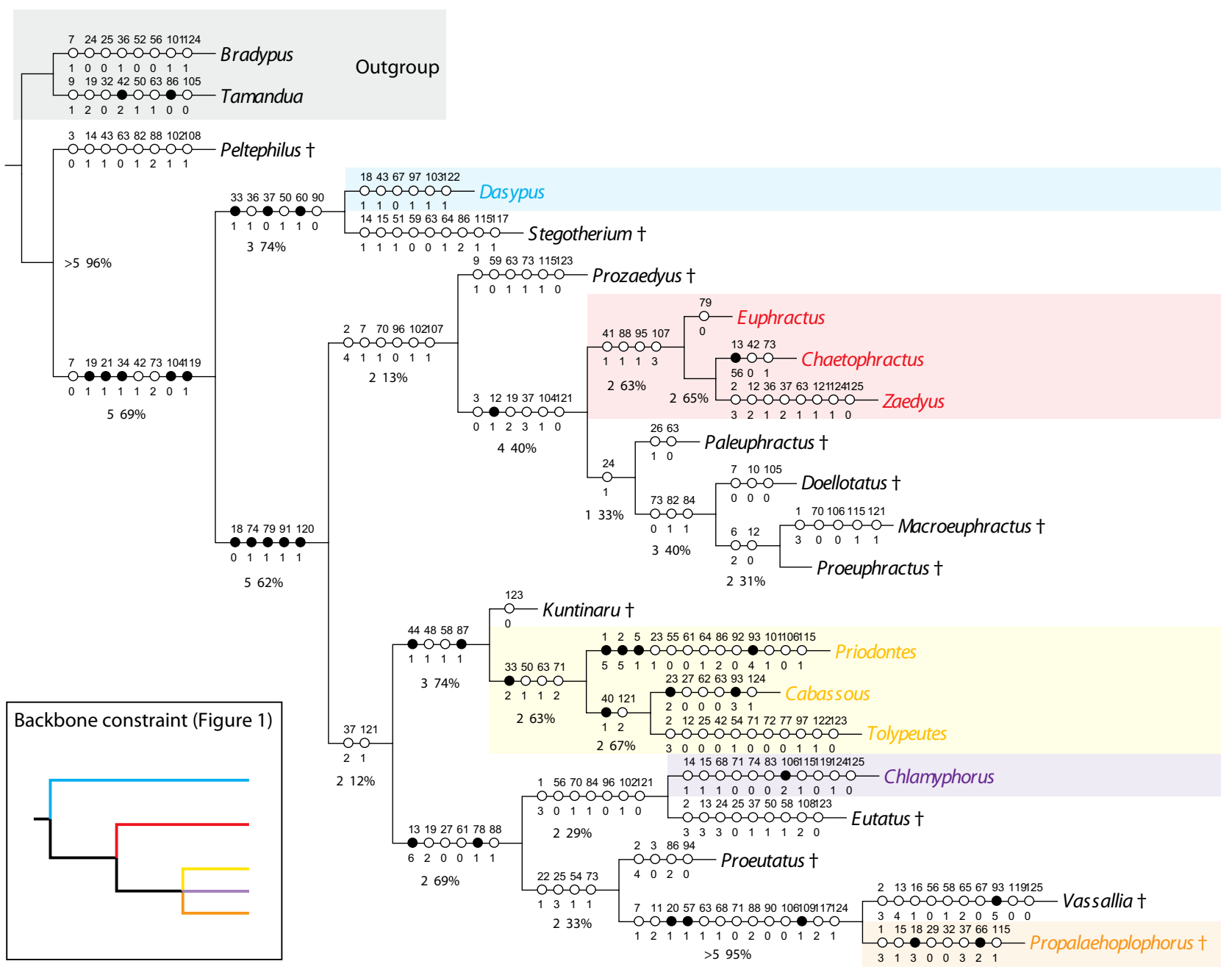

Fig. 2 Maximum parsimony phylogeny reconstructed from Billet et al. (2011)'s morphological matrix using PAUP*, constrained to be consistent with our molecular results in Fig. 1. Unambiguous synapomorphies are plotted along branches (black $=$ nonhomoplasious, white $=$ homoplasious) using WINCLADA v1.00.08 (Nixon 2002). Bremer support values (integer) and parsimony bootstrap (\%) are displayed below each branch. Coloured lineages correspond to clades in Fig. 1, grey shading indicates the out-group, and uncoloured lineages represent additional fossil taxa (marked with a $\dagger$ ). Inset shows the backbone constraint enforced, such that relationships among taxa remained consistent with Fig. 1. Character and character state definitions are available in the Supporting Material, and character scoring is unchanged from Billet et al. (2011). 
currently recognized. Billet et al. (2011) recovered a clade comprising extant Euphractinae and the pink fairy armadillo (Chlamyphorus) along with several fossil taxa including glyptodonts (represented by the Miocene Propalaehoplophorus), which they found was strongly supported by five putatively unambiguous nonhomoplasious (i.e. not convergently evolved) synapomorphies (Supporting information). Our results indicate that these five state changes have either occurred multiple times among cingulates (parallel evolution) or are ancestral (plesiomorphic) and secondarily reversed in some lineages (e.g. Tolypeutinae). Similarly, one additional putatively nonhomoplasious-derived character states that Billet et al. (2011) identified as diagnosing a clade including Glyptodontoidea and Euphractinae but excluding Chlamyphorinae and Tolypeutinae (a straight and oblique profile of the zygomatic arch; character 69, state 2), and another diagnosing a wider clade including Chlamyphorinae (width of the glenoid fossa approximately equivalent to length; character 88 , state 1), also appear to have evolved several times among cingulates. Interestingly, no unambiguous nonhomoplasious morphological synapomorphies diagnose the clade comprising Tolypeutinae and Chlamyphorinae (or a wider clade including glyptodonts), despite unequivocal support for this grouping from molecular data (Fig. 1).

Although the power of Billet et al. (2011)'s morphological matrix for resolving relationships among cingulate higher taxa may be limited, it is interesting that a monophyletic Glyptodontoidea (glyptodonts and pampatheres) remains strongly supported (Fig. 2). Further, our topologically constrained analysis of the morphological data favours a clade comprising glyptodonts, pampatheres (represented by Vassalia), the pink fairy armadillo and the extinct genera Eutatus and Proeutatus. Although support for this grouping is relatively weak (Bremer $=2$; Parsimony Bootstrap, PBS $=<50 \%$ ), two unambiguous nonhomoplasious synapomorphies appear to diagnose this clade: a substantially dorsal position of the auditory region with respect to the palate (character 78 , state 1 ) and a $\geq 90^{\circ}$ angle between the toothrow and the anterior edge of ascending ramus (character 13, state 6). Further, Eutatus and Proeutatus show some degree of specialization towards herbivory (Vizcaíno \& Bargo 1998), suggesting that this clade may represent a single radiation of herbivorous forms with varying degrees of morphological specialization and gigantism.

The pink fairy armadillo is exceptional in comparison to Vassalia, Propalaehoplophorus, Proeutatus and Eutatus, as it shows no particular specialization for herbivory. Further, a close association between the glyptodonts and the fairy armadillos (Chlamyphorinae) is surprising, as these taxa are among the most derived cingulates: glyptodonts were generally large-bodied and heavily armoured, while the fairy armadillos are tiny and adapted for burrowing. However, in addition to the synapomorphies described above, the pink fairy armadillo, Vassallia (a pampatheriid) and Propalaehoplophorus also share a lateral orientation of the posterior root of the zygoma (character 68, state 1)-an apparently derived trait not observed in any other sampled taxon. Due to the highly divergent morphology of these taxa, it seems unlikely that any shared derived characters could be the result of convergent evolution, so future studies should consider the possibility that insectivorous habits of the fairy armadillos are secondarily reversed from a more herbivorous ancestor. In any case, the close relationship between fairy armadillos and glyptodonts suggested by our analyses of Billet et al. (2011)'s morphological matrix testifies to our patchy knowledge about the skeletal transformations that occurred during the first steps of cingulate evolution.

Our analyses of Billet et al. (2011)'s data support their original taxonomic assignment of the Oligocene armadillo Kuntinaru as a (stem) member of Tolypeutinae (Fig. 2). Kuntinaru therefore represents a valuable calibration for molecular dating (e.g. Gibb et al. 2015). Since the first unequivocal glyptodont remains are around 10 million years older than Kuntinaru, Doedicurus is potentially an even more important calibration point. Using both Kuntinaru and Doedicurus to constrain the age of our phylogeny (Fig. 1) results in node age estimates that support and broadly overlap with those of previous studies (Delsuc et al. 2004, 2012; Gibb et al. 2015). However, in many cases, our estimates are more precise (Table S4, Supporting information). For example, Gibb et al. (2015) estimated a 95\% highest posterior density (HPD) of 31.5-44.7 Ma (a range of 13.2 million years) for the age of Chlamyphoridae while we estimated a 95\% HPD of 37.4-43.9 Ma (a range of 6.5 million years). Similarly, their estimate for the crown age of Cingulata (95\% HPD of 38.3-52.1 Ma) was 12.1 million years wider than ours (95\% HPD of 46.9-58.6 Ma).

Our results suggest that the osteological novelties of glyptodonts and their acquisition of herbivory must have evolved in a relatively short period of time during the Late Eocene to Early Miocene (Fig. 1), as these features are already present in the Miocene Propalaehoplophoridae (the oldest and most complete fossil glyptodonts). Rapid morphological evolution of glyptodonts may partially explain the scarcity of fossils recording their early history, and the lack of morphological synapomorphies uniting Glyptodontoidea, Chlamyphorinae and Tolypeutinae. In addition, it is notable that during the Late Eocene and Oligocene, the climate in South America was becoming cooler and 
drier, leading to a gradual replacement of wet forest environments by more open woodland and savannah (Ortiz-Jaureguizar \& Cladera 2006; Iglesias et al. 2011). It is possible that early glyptodonts had a predisposition or some degree of specialization towards herbivory (as for Proeutatus and Eutatus) and that expansion of new habitats and more abundant food sources (e.g. grasslands) facilitated the evolution of gigantism in these ancestral forms (and early pampatheres, to a lesser extent).

Larger body mass would have precluded early glyptodonts from sheltering in burrows as modern armadillos do, so the glyptodonts comparatively heavy armour and additional protective structures (described by Zurita et al. 2010) may have evolved to compensate for this increased vulnerability. It is also possible that gigantism itself evolved primarily as a defence against predation, which would explain why the largest glyptodonts (e.g. Doedicurus, Panochthus) are known from the Early Pleistocene (Soibelzon et al. 2010; Cione et al. 2015), as prePleistocene South American carnivores were generally relatively small compared to Pliocene/Pleistocene species such as the giant short-faced bear (Arctotherium angustidens, $900 \mathrm{~kg}$ ), sabre-toothed cats (Smilodon populator, $290 \mathrm{~kg}$; Homotherium sp., $190 \mathrm{~kg}$ ) and the jaguar (Panthera onca, $71.2 \mathrm{~kg}$ ) (Prevosti \& Vizcaíno 2006; Cione et al. 2015). Alternatively (or complementarily), once heavy armour evolved in early glyptodonts a trend towards increasing armour and size may have been driven by intraspecific competition (Alexander et al. 1999; Blanco et al. 2009). Ultimately, our improved estimates for the phylogeny and evolutionary timeline of xenarthrans have yielded important insights into the evolutionary history of glyptodonts and represent critical resources for improving interpretation of the fossil record of Cenozoic xenarthrans and future macroevolutionary and biogeographic studies.

\section{Note added in proof}

Our molecular phylogenetic results are supported by the independent study of Delsuc et al. (2016). The latter did not include a morphological analysis.

\section{Acknowledgements}

We thank the Smithsonian Institute (D. Lunde, K. Helgen, N. Edmison) and the Louisiana State University (J. Esseltyn, D. Dittman) for access to specimens of extant xenarthran species. R. Antinori and E. Donantueno (Subsecretaría de Recursos Hídricos), and C. Rodríguez (Museo Histórico Enrique Múlgura, Gral Belgrano) helped with the excavation. We are additionally grateful to F. Iacona, N. Umenico, J. Salgado, A. Carignano, F.S. Lara, S. Rodríguez, S. Lucero and the Bonini and Scanferla families for their help in the field. Grid computing facilities were provided by eResearch SA and CIPRES (Cyberinfrastructure for Phylogenetic Research). The comments of M.R. Ciancio and M. Arnal (Museo de La Plata) improved the final version of the manuscript.

\section{References}

Alexander RM, Farina RA, Vizcaíno SF (1999) Tail blow energy and carapace fractures in a large glyptodont (Mammalia, Xenarthra). Zoological Journal of the Linnean Society, 126, $41-49$.

Barnosky AD, Koch PL, Feranec RS, Wing SL, Shabel AB (2004) Assessing the causes of late Pleistocene extinctions on the continents. Science, 306, 70-75.

Bergvist LP, Abrantes EAL, Avilla LD (2004) The Xenarthra (Mammalia) of São Jose de Itaboraí Basin (upper Paleocene, Itaboraían), Rio de Janeiro, Brazil. Geodiversitas, 26, 323-337.

Billet G, Hautier L, de Muizon C, Valentin X (2011) Oldest cingulate skulls provide congruence between morphological and molecular scenarios of armadillo evolution. Proceedings of the Royal Society B: Biological Sciences, 278, 2791-2797.

Blanco RE, Jones WW, Rinderknecht A (2009) The sweet spot of a biological hammer: the centre of percussion of glyptodont (Mammalia: Xenarthra) tail clubs. Proceedings of the Royal Society of London B: Biological Sciences, 276, 3971-3978.

Brotherton P, Haak W, Templeton J et al. (2013) Neolithic mitochondrial haplogroup $\mathrm{H}$ genomes and the genetic origins of Europeans. Nature Communications, 4, 1764.

Chornogubsky L (2011) New remains of the dryolestoid mammal Leonardus cuspidatus from the Los Alamitos Formation (Late Cretaceous, Argentina). Paläontologische Zeitschrift, 85, 343-350.

Cione A, Gasparini G, Soibelzon E, Soibelzon L, Tonni E (2015). The Great American Biotic Interchange. A South American perspective. Springer Briefs in Earth System Sciences. South America and the Southern Hemisphere, Amsterdam, Netherlands.

Clack AA, MacPhee RD, Poinar HN (2012) Mylodon darwinii DNA sequences from ancient fecal hair shafts. Annals of Anatomy, 194, 26-30.

Delsuc F, Vizcaíno SF, Douzery EJ (2004) Influence of Tertiary paleoenvironmental changes on the diversification of South American mammals: a relaxed molecular clock study within xenarthrans. BMC Evolutionary Biology, 4, 1-13.

Delsuc F, Superina M, Tilak M-K, Douzery EJP, Hassanin A (2012) Molecular phylogenetics unveils the ancient evolutionary origins of the enigmatic fairy armadillos. Molecular Phylogenetics and Evolution, 62, 673-680.

Delsuc F, Gibb GC, Kuch M, et al. (2016) The phylogenetic affinities of the extinct glyptodonts. Current Biology, 26, R155R156.

Drummond AJ, Rambaut A (2007) BEAST: Bayesian evolutionary analysis by sampling trees. BMC Evolutionary Biology, 7, 214

Engelmann G (1985) The phylogeny of the Xenarthra. In: The Ecology and Evolution of Armadillos, Sloths, and Vermilinguas (ed. Montgomery GG), pp. 51-63. Smithsonian Institution Press, Washington, District of Columbia.

Farina RA, Vizcaíno SF (2001) Carved teeth and strange jaws: how glyptodonts masticated. Acta Palaeontologica Polonica, 46, 219-234. 
Fernicola JC (2008) Nuevos aportes para la sistemática de los Glyptodontia Ameghino 1889 (Mammalia, Xenarthra, Cingulata). Ameghiniana, 45, 553-574.

Fucks E, Pisano MF, Huarte RA et al. (2015) Stratigraphy of the fluvial deposits of the Salado river basin, Buenos Aires Province: Lithology, chronology and paleoclimate. Journal of South American Earth Sciences, 60, 129-139.

Gardner AL (2005) Cingulata. In: Mammal Species of the World: A Taxonomic and Geographic Reference (eds Wilson DE, Reeder DM), pp. 94-99. The Johns Hopkins University Press, Baltimore.

Gaudin TJ, Croft DA (2015) Paleogene Xenarthra and the evolution of South American mammals. Journal of Mammalogy, 96, 622-663.

Gaudin TJ, McDonald HG (2008) Morphology-based investigations of the phylogenetic relationships among extant and fossil xenarthrans. In: The Biology of the Xenarthra (eds Vizcaino SF, Loughry WJ), pp. 24-36. University Press of Florida, Gainesville.

Gaudin TJ, Wible JR (2006) The phylogeny of the living and extinct armadillos (Mammalia, Xenarthra, Cingulata): a craniodental analysis. In: Amniote Paleobiology: Perspectives on the Evolution of Mammals, Birds, and Reptiles (eds Carrano MT, Gaudin TJ, Blob RW, Wible JR), pp. 153-198. University of Chicago Press, Chicago, Illinois.

Gelfo JN, Goin FJ, Woodburne MO, Muizon CD (2009) Biochronological relationships of the earliest South American Paleogene mammalian faunas. Palaeontology, 52, 251-269.

Gibb GC, Condamine FL, Kuch M et al. (2015) Shotgun mitogenomics provides a reference phylogenetic framework and timescale for living xenarthrans. Molecular Biology and Evolution, 33, 621-642.

Gillette DD, Ray CE (1981) Glyptodonts of North America. Smithsonian Contributions to Paleobiology, 40, 1-255.

Góis F, González Ruiz LR, Scillato-Yané GJ, Soibelzon E (2015) A peculiar new Pampatheriidae (Mammalia: Xenarthra: Cingulata) from the Pleistocene of Argentina and comments on Pampatheriidae diversity. PLoS One, 10, e0128296.

Greenwood AD, Castresana J, Feldmaier-Fuchs G, Paabo S (2001) A molecular phylogeny of two extinct sloths. Molecular Phylogenetics and Evolution, 18, 94-103.

Hoss M, Dilling A, Currant A, Paabo S (1996) Molecular phylogeny of the extinct ground sloth Mylodon darwinii. Proceedings of the National Academy of Sciences of the United States of America, 93, 181-185.

Iglesias ARI, Artabe AE, Morel EM (2011) The evolution of Patagonian climate and vegetation from the Mesozoic to the present. Biological Journal of the Linnaean Society, 103, 409-422.

Kay RF, Macfadden BJ, Madden RH, Sandeman H, Anaya F (1998) Revised age of the Salla beds, Bolivia, and its bearing on the age of the Deseadan South American Land Mammal "Age". Journal of Vertebrate Paleontology, 18, 189-199.

Kay RF, Madden RH, Vucetich MG et al. (1999) Revised geochronology of the Casamayoran South American Land Mammal Age: climatic and biotic implications. Proceedings of the National Academy of Sciences of the United States of America, 96, 13235-13240.

Lanfear R, Calcott B, Ho SY, Guindon S (2012) PartitionFinder: combined selection of partitioning schemes and substitution. Molecular Biology and Evolution, 29, 1537-1719.
Llamas B, Brotherton P, Mitchell KJ et al. (2014) Late Pleistocene Australian marsupial DNA clarifies the affinities of extinct megafaunal kangaroos and wallabies. Molecular Biology and Evolution, 32, 574-584.

McKenna MC, Bell SK (1997) Xenarthra. In: Classification of Mammals Above the Species Level, (eds McKenna MC, Bell SK), pp. 82-102. Columbia University Press, New York.

Mitchell KJ, Llamas B, Soubrier J et al. (2014) Ancient DNA reveals elephant birds and kiwi are sister taxa and clarifies ratite bird evolution. Science, 344, 898-900.

Nixon KC (2002) WinClada ver. 1.00.08. Published by the author, Ithaca, New York.

Nowack RM (1999) Walker's Mammals of the World. Johns Hopkins University Press, Baltimore.

Oliveira EV, Bergqvist LP (1998) A new Paleocene armadillo (Mammalia, Dasypodoidea) from the Itaboraí Basin, Brazil. Paleógeno de América del Sur y de la Península Antártica. Asociación Paleontológica Argentina. Publicación Especial, 5, 35-40.

Orlando L, Male D, Alberdi MT et al. (2008) Ancient DNA clarifies the evolutionary history of American late Pleistocene equids. Journal of Molecular Evolution, 66, 533-538.

Orlando L, Metcalf JL, Alberdi MT et al. (2009) Revising the recent evolutionary history of equids using ancient DNA. Proceedings of the National Academy of Sciences of the United States of America, 106, 21754-21759.

Ortiz-Jaureguizar E, Cladera GA (2006) Paleoenvironmental evolution of southern South America during the Cenozoic. Journal of Arid Environments, 66, 498-532.

Patterson B, Pascual R (1968) The fossil mammal fauna of South America. The Quarterly Review of Biology, 43, 409-451.

Patterson B, Pascual R (1972) The fossil mammal fauna of South America. In: Evolution, Mammals, and Southern Continents (eds Keast A, Erk FC, Glass B), pp. 247-309. State University of New York Press, Albany.

Porpino KdO, Fernicola JC, Bergqvist LP (2010) Revisiting the intertropical Brazilian species Hoplophorus euphractus (Cingulata, Glyptodontoidea) and the phylogenetic affinities of Hoplophorus. Journal of Vertebrate Paleontology, 30, 911-927.

Prescott GW, Williams DR, Balmford A, Green RE, Manica A (2012) Quantitative global analysis of the role of climate and people in explaining late Quaternary megafaunal extinctions. Proceedings of the National Academy of Sciences of the United States of America, 109, 4527-4531.

Prevosti FJ, Vizcaíno SF (2006) Paleoecology of the large carnivore guild from the late Pleistocene of Argentina. Acta Palaeontologica Polonica, 51, 407-422.

Ronquist F, Teslenko M, van der Mark P et al. (2012) MrBayes 3.2: efficient Bayesian phylogenetic inference and model choice across a Large model space. Systematic Biology, 61, 539-542.

Rose KD (2006) The Beginning of the Age of Mammals. The John Hopkins University Press, Baltimore, Maryland.

Scanferla A, Bonini R, Pomi L, Fucks E, Molinari A (2013) New Late Pleistocene megafaunal assemblage with well-supported chronology from the Pampas of southern South America. Quaternary International, 305, 97-103.

Simpson GG (1948) The beginning of the age of mammals in South America. Part 1. Introduction. Systematics: Marsupialia, Edentata, Condylarthra, Litopterna and Notioprogonia. Bulletin of the American Museum of Natural History, 91, 1232. 
Soibelzon E, Zurita AE, Carlini AA (2006) Glyptodon munizi Ameghino (Mammalia, Cingulata, Glyptodontidae): redescripción y anatomía. Ameghiniana, 43, 377-384.

Soibelzon E, Miño-Boilini AR, Zurita AE, Krmpotic CM (2010) Los Xenarthra (Mammalia) del Ensenadense (Pleistoceno Inferior a Medio) de la Región Pampeana (Argentina). Revista Mexicana de Ciencias Geologicas, 27, 449-469.

Stamatakis A (2014) RAxML version 8: a tool for phylogenetic analysis and post-analysis of large phylogenies. Bioinformatics, 30, 1312-1313.

Stegner MA, Holmes M (2013) Using palaeontological data to assess mammalian community structure: potential aid in conservation planning. Palaeogeography, Palaeoclimatology, Palaeoecology, 372, 138-146.

Swofford DL (2002) PAUP*. Phylogenetic Analysis Using Parsimony ( ${ }^{*}$ and Other Methods). Sinauer Associates, Sunderland, Massachussets.

Vizcaíno SF, Bargo MS (1998) The masticatory apparatus of the armadillo Eutatus (Mammalia, Cingulata) and some allied genera: paleobiology and evolution. Paleobiology, 24, 371-383.

Vizcaíno SF, Fariña RA, Bargo MS, De Iullis G (2004) Functional and phylogenetic assessment of the masticatory adaptations in Cingulata (Mammalia, Xenarthra). Ameghiniana, 41, 651-664.

Woodburne MO, Goin FJ, Bond M et al. (2014) Paleogene land mammal faunas of South America; a response to global climatic changes and indigenous floral diversity. Journal of Mammalian Evolution, 21, 1-73.

Zurita AE, Miño-Boilini E, Soibelzon ÁR et al. (2009a) The Diversity of (Xenarthra) in the Tarija valley (Bolivia): systematic, biostratigraphic and paleobiogeographic aspects of a particular assemblage. Neus Jahrbuch fur geologie und palaontologie, 25, 225-237.

Zurita AE, Soibelzon E, Scillato-Yane GJ, Cenizo M (2009b) The earliest record of Neuryurus Ameghino (Mammalia, Glyptodontidae, Hoplophorinae). Alcheringa: An Australasian Journal of Palaeontology, 33, 49-57.

Zurita AE, Soibelzon LH, Soibelzon E et al. (2010) Accessory protection structures in Glyptodon Owen (Xenarthra, Cingulata, Glyptodontidae). Annales de Paleontologie, 96, 1-11.

Zurita AE, González Ruiz LR, Gómez-Cruz AJ, Arenas-Mosquera JE (2013) The most complete known Neogene Glyptodontidae (Mammalia, Xenarthra, Cingulata) from northern South America: taxonomic, paleobiogeographic, and phylogenetic implications. Journal of Vertebrate Paleontology, 33, 696-708.
A.S. and A.C. conceived of the study; A.S., J.O. and R.B. described the fossil site and collected Doedicurus sp. specimen; E.S. collected specimens of living armadillos; K.J.M. performed the phylogenetic analyses and wrote the manuscript, with help from all authors.

\section{Data accessibility}

Mitochondrial genome consensus sequences presented in this study are available on GenBank (Accession nos: KX098449, KX180156-KX180158). All sequencing reads, scripts, alignments, analysis input files and trees are uploaded to the Dryad Digital Repository (doi: 10.5061/ dryad.2dr33)

\section{Supporting information}

Additional supporting information may be found in the online version of this article.

Appendix S1. Supplementary methods and discussion.

Table S1 Accession numbers for mitogenome sequences used for phylogenetic analyses.

Table S2 Sequencing library structure.

Table S3 Primers used for library amplification.

Table S4 Mitochondrial sequence used to design RNA baits for hybridisation enrichment

Table S5 Consensus sequence details for extant armadillo species.

Table S6 Output from PartitionFinder for analysis in RAXML.

Table S7 Output from PartitionFinder for analysis in MRBAYES.

Table S8 Output from PartitionFinder for analysis in BEAST. 